\title{
Scaffolding Sesuai Gaya Belajar Terhadap Kemampuan Berpikir Kreatif Matematis Siswa SMP dalam Menyelesaikan Soal HOTS
}

\author{
Firnanda Muharrima \\ Program Studi Pendidikan Matematika, FMIPA, Universitas Negeri Surabaya \\ firnanda.17030174039@mhs.unesa.ac.id \\ Janet Trineke Manoy \\ Program Studi Pendidikan Matematika, FMIPA, Universitas Negeri Surabaya \\ janetmanoy@unesa.ac.id
}

\begin{abstract}
Abstrak
Kemampuan matematika siswa Indonesia pada PISA 2018 menempati peringkat ke 72 dari total 78 negara, hal ini menunjukkan bahwa siswa Indonesia belum mampu menyelesaikan soal berupa masalah yang memerlukan keterampilan berpikir tingkat tinggi diantaranya keterampilan berpikir kritis dan kreatif. Penelitian ini bertujuan untuk mendeskrispikan kemampuan berpikir kreatif siswa SMP yang diberikan scaffolding sesuai gaya belajar dalam menyelesaikan soal HOTS (High Order Thinking Skills) materi kesebangunan dan kekongruenan. Subjek penelitian diambil dari 3 siswa kelas 9 SMP Negeri 31 Surabaya, dimana setiap siswa mewakili gaya belajar visual, auditori, dan kinestetik. Teknik pengumpulan data menggunakan tes gaya belajar, tes kemampuan berpikir kreatif, dan wawancara. Scaffolding diberikan kepada siswa yang tidak kreatif atau tidak mampu menyelesaikan Tes Kemampuan Berpikir Kreatif (TKBK I). Setelah diberikan scaffolding sesuai gaya belajar, subjek dapat menyelesaikan TKBK I, TKBK II, serta menggunakan cara lain yang berbeda. Kemampuan berpikir kreatif matematis subjek dengan gaya belajar kinestetik meningkat dari tidak kreatif menjeadi cukup kreatif, subjek dengan gaya belajar audio dan visual meningkat dari tidak kreatif menjadi kreatif. Pada proses pemberian scaffolding, subjek dengan gaya belajar visual dan audio lebih cepat menerima dan memahami bantuan dari peneliti, sedangkan subjek dengan gaya belajar kinestetik membutuhkan waktu yang lebih lama dan penjelasan yang lebih rinci. Disimpulkan bahwa scaffolding sesuai gaya belajar dapat meningkatkan kemampuan berpikir kreatif matematis siswa.
\end{abstract}

Kata Kunci: scaffolding, gaya belajar, berpikir kreatif, SMP

\begin{abstract}
Indonesian students' mathematical ability on PISA is ranked 72 of 78 countries, this shows that Indonesian students have not been able to solve problems in the form of problems that require HOTS (High Order Thinking Skills) including critical and creative thinking skills. This study aims to describe the creative thinking skills of junior high school students who are given scaffolding according to their learning styles in solving HOTS questions on similarity and congruence material. The research subjects were taken of 3 students from 9th grade students of SMP Negeri 31 Surabaya, where each student represented a visual, auditory, and kinesthetic learning style. Collecting data used learning style tests, creative thinking skills tests, and interviews. Scaffolding is given to students who are not creative or unable to complete the Creative Thinking Ability Test (TKBK I). After being given scaffolding according to the learning style, the subject can complete TKBK I, TKBK II, and use other different methods. The mathematical creative thinking ability of subjects with a kinesthetic learning style increased from uncreative to quite creative, and subjects with audio and visual learning styles increased from uncreative to creative. In the process of giving scaffolding, subjects with visual and audio learning styles receive and understand help from researchers faster, while subjects with kinesthetic learning styles require longer time and more detailed explanations. It was concluded that scaffolding according to learning styles could improve students' mathematical creative thinking skills.
\end{abstract}

Keywords: scaffolding, learning style, creative thinking, junior high school

\section{PENDAHULUAN}

Berdasarkan hasil PISA 2018, siswa Indonesia mendapat nilai lebih rendah dari rata-rata OECD (Organitation for
Economic Cooperation and Development) dalam hal pengetahuan dan keterampilan membaca, matematika dan sains (OECD, 2019). Kemampuan matematika siswa Indonesia menempati peringkat ke 72 dari total 78 negara 
(OECD, 2018), hal ini menunjukkan bahwa siswa belum mampu menyelesaikan permasalahan yang memerlukan keterampilan berpikir tingkat tinggi diantaranya keterampilan berpikir kreatif (King dkk, 2018; Nursalam dkk, 2018). Dengan soal HOTS siswa akan mampu memecahkan masalah, mampu mengonstruksi penjelasan, dan mampu memahami hal-hal kompleks menjadi lebih jelas (Widodo \& Kadarwati, 2013); dapat membiasakan siswa untuk berpikir kreatif (Choridah, 2013), dapat meningkatkan motivasi serta prestasi siswa, siswa terlibat dalam pemikiran tentang hal-hal tertentu dan termotivasi untuk mempelajari hal tersebut, meningkatkan rasa kontrol siswa terhadap suatu ide (Brookhart, 2010. P 12). Dengan demikian siswa akan memahami konsep lebih baik dengan berpikir kreatif ketika menyelesaikan dan memecahkan soal HOTS.

Salah satu implementasi kurikulum 2013 yaitu menerapkan HOTS dalam kegiatan maupun evaluasi pembelajaran dan meningkatkan presentase soal kategori HOTS pada Ujian Nasional (UN) terutama untuk materi matematika. Kesebangunan dan kekongruenan merupakan salah satu materi dalam kategori HOTS pada soal UN, namun, nilai rata-rata UN matematika jenjang SMP pada tahun 2018 merosot tajam yaitu dari 52,59 menjadi 31,38, sehingga diperlukan suatu perhatian khusus terhadap soal HOTS pada materi matematika di jenjang SMP (Badjeber \& Purwaningrum, 2018).

Pemikiran Tingkat Tinggi mengacu pada pemikiran dan strategi pemecahan masalah yang memungkinkan seseorang untuk mengakses, menyortir dan mencerna beberapa informasi (Manoy, 2014). Selain dalam menyelesaikan soal HOTS, kemampuan berpikir kreatif sangat dibutuhkan dalam kehidupan sehari-hari. Siswa yang memiliki kemampuan berpikir kreatif akan memiliki keterampilan berpikir lancar, berpikir luwes (fleksibel), berpikir orisinal, dan berpikir terperinci (elaborasi) (Munandar, 2014). Berpikir kreatif dapat memiliki arti pemikiran lancar (kelancaran), menghasilkan banyak gagasan atau jawaban yang relevan (keluwesan), menghasilkan gagasan atau jawaban yang beragam, arah pemikiran yang berbeda sehingga memberikan jawaban yang tidak lazim (Fardah, 2012).

Komponen-komponen yang digunakan untuk menentukan kemampuan berpikir kreatif antara lain (1) Kefasihan, yaitu siswa mampu menyelesaikan masalah dengan bermacam-macam solusi dan jawaban; (2) Fleksibilitas, yaitu siswa mampu menyelesaikan (menyatakan) dalam satu cara kemudian dalam cara lain dan siswa mendiskusikan berbagai metode penyelesaian; (3) Kebaruan, yaitu siswa mampu menyelesaikan masalah dengan jawaban yang tidak biasa dilakukan oleh siswa pada tahap perkembangan mereka atau tingkat pengetahuannya (Siwono, 2007). Kemampuan berpikir kreatif matematis disajikan pada Tabel 1 berikut.

Tabel 1. Deskripsi Tingkat Kemampuan Berpikir Kreatif

\begin{tabular}{|l|l|}
\hline \multicolumn{1}{|c|}{ Tingkatan } & \multicolumn{2}{|c|}{ Deskripsi } \\
\hline Kreatif & $\begin{array}{l}\text { Siswa dalam memecahan masalah } \\
\text { memenuhi } \\
\text { fleksibilitas, dan kebaruan atau kebaruan } \\
\text { dan fleksibilitas }\end{array}$ \\
\hline 3.Kreatif & $\begin{array}{l}\text { Siswa dalam memecahan masalah } \\
\text { memenuhi kriteria kefasihan dan } \\
\text { fleksibilitas atau kefasihan dan kebaruan }\end{array}$ \\
\hline $\begin{array}{l}\text { 2.Cukup } \\
\text { Kreatif }\end{array}$ & $\begin{array}{l}\text { Siswa dalam memecahan masalah hanya } \\
\text { memenuhi kriteria fleksibilitas atau } \\
\text { kebaruan. }\end{array}$ \\
\hline $\begin{array}{l}\text { 1.Kurang } \\
\text { kreatif }\end{array}$ & $\begin{array}{l}\text { Siswa dalam memecahan masalah hanya } \\
\text { memenuhi kriteria kefasihan. }\end{array}$ \\
\hline $\begin{array}{l}\text { 0.Tidak } \\
\text { Kreatif }\end{array}$ & $\begin{array}{l}\text { Siswa dalam memecahan masalah tidak } \\
\text { memenuhi satu kriteria pun dari kriteria } \\
\text { kefasihan, fleksibilitas, dan kebaruan. }\end{array}$ \\
\hline
\end{tabular}

(Siswono, 2010)

Gaya belajar mengacu pada cara belajar yang lebih disukai siswa dan tentunya setiap siswa memiliki gaya belajar yang menentukan bagaimana mereka belajar dan berinteraksi dengan lingkungannya. Gaya belajar merupakan kombinasi dari bagaimana seseorang menyerap, mengatur serta mengolah informasi (DePorter \& Hernacki, 2008). Mengenali gaya belajar sendiri, seseorang akan dapat menentukan cara belajar yang lebih efektif (Wahyuni, 2017). Gaya belajar merujuk pada bagaimana seseorang menerima, fokus, memaknai, dan memproses informasi baru kemudian mengubahnya untuk membangun keterampilan baru. Duun dan Griggs dalam (Fayombo, 2015), Seseorang memiliki gaya belajar yang mendominasinya yaitu gaya belajar visual (V), gaya belajar auditori (A), dan gaya belajar kinestetik (K), atau disingkat VAK (Hamzah, 2008). Richard Bandler, dkk dalam Zahroh dan Beni (2014) telah mengidentifikasikan tiga gaya belajar yaitu (1) Visual, belajar melalui melihat sesuatu; (2) Auditori, belajar melalui mendengar sesuatu; (3) Kinestetik, belajar melalui aktifitas fisik dan keterlibatan langsung. Dengan mengetahui gaya belajar siswa, guru akan lebih mudah dalam mengolah dan melaksanakan pembelajaran (Permatasari dkk, 2018), guru mengubah sistem pengajarannya dan menerapkan langkah-langkah pembelajaran yang memotivasi siswa untuk berpikir kreatif (Azhari \& Somakim, 2014).

Kemampuan berpikir kreatif siswa dalam bidang matematika belum mampu untuk dikembangkan melalui pembelajaran inovatif (Sriwongchai dkk, 2015), sehingga diperlukan pembelajaran yang sesuai. Scaffolding sesuai gaya belajar dapat membantu siswa dalam meningkatkan 
kemampuan berpikir kreatif matematisnya (Wahyudi, 2017). Scaffolding dikategorikan menjadi tiga level (Anghileri, 2006), yaitu Level 1: Environmental provision; Level 2: Explaining, reviewing, and restructuring; dan Level 3: Developing conceptual thinking. Pada level 1, bantuan yang diberikan guru yaitu menyiapkan lingkungan belajar siswa. Pada level 2, terdapat interaksi langsung antara guru dan siswa. Bentuk interaksi yang dimaksud, diantaranya yaitu menjelaskan konsep yang dipelajari, memfokuskan kembali perhatian siswa, dan membangun ulang pemahaman dengan menyederhanakan sesuatu yang abstrak agar dapat dipahami siswa. Pada level 3, terdapat interaksi pengajaran antara siswa dan guru dalam pengembangan konseptual berpikir dengan menciptakan kesempatan untuk mengungkapkan pemahaman.

Penelitian Wahyudi (2017), tentang scaffolding bagi mahasiswa calon guru sesuai gaya belajarnya, menginspirasi peneliti untuk mengetahui lebih rinci tentang kemampuan berpikir kreatif matematis siswa pada jenjang SMP sebelum dan sesudah pemberian scaffolding sesuai gaya belajar jika diberikan soal HOTS. Perbedaan penelitian ini dengan penelitian Wahyudi terletak pada subjek penelitian. Subjek penelitian ini yaitu siswa jenjang SMP sedangkan subjek penelitian Wahyudi yaitu mahasiswa Proses scaffolding pada penelitian ini diperuntukan bagi siswa dengan kemampuan berpikir tidak kreatif.

\section{METODE}

Penelitian ini termasuk jenis penelitian deskriptif dengan pendekatan kualitatif, dimana akan dipilih 3 subjek dari 15 siswa kelas 9 di SMP Negeri 31 Surabaya. Penelitian ini akan mendeskripsikan kemampuan berpikir kreatif siswa dan proses scaffolding dalam menyelesaikan soal HOTS. Instrumen yang digunakan yaitu tes gaya belajar, wawancara, dan tes kemampuan berpikir kreatif matematis. Tes kemampuan berpikir kreatif matematis antara lain Tes Kemampuan Berpikir Kreatif (TKBK I) dan TKBK II. Langkah-langkah yang digunakan yaitu (1) Memberikan angket gaya belajar dan TKBK I; (2) Menganalisis hasil tes gaya belajar dan kemampuan berpikir kreatif yang diperoleh; (3) Melakukan wawancara kepada subjek kategori tidak kreatif; (4) Menentukan subjek penelitian atas pertimbangan gaya belajar dan kemampuan berpikit kreatif; (5) Proses scaffolding sesuai gaya belajar dengan mengerjakan kembali TKBK I serta memberikan TKBK II.

Scaffolding untuk gaya belajar kinestetik menggunakan media alat peraga. Scaffolding untuk gaya belajar visual menggunakan media simulasi gambar. Sedangkan untuk gaya belajar audio akan diberikan penjelasan dan contoh soal lebih.
Tes kemampuan berpikir kreatif matematis menggunakan soal HOTS pada materi kesebangunan dan kekongruenan yang telah divalidasi oleh validator. Pemilihan materi ini karena esebangunan dan kekongruenan merupakan salah satu materi dalam kategori HOTS pada soal UN tahun 2018. Soal HOTS yang disertai gambar membantu siswa memahami soal tersebut, dan siswa dapat berpikir secara luas untuk menemukan tantangan baru (Heong dkk, 2011). TKBK I terdapat pada Gambar 1 dan TKBK II terdapat pada Gambar 2.

Andi ingin mengetahui lebar sungai, untuk itu dia menancapkan tongkat disebrang pohon sehingga tongkat berada pada posisi A, B, C, dan D dengan ukuran seperti pada gambar berikut.

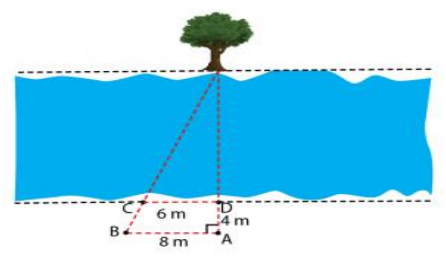

Berapa lebar sungai tersebut? Selesaikan dengan berbagai macam cara.

Gambar 1. Instrumen TKBK I

Sebuah gedung mempunyai tinggi 24 meter. Pada saat yang sama, Budi dengan tinggi 1,5 meter berdiri di depan gedung mempunyai bayangan 0,5 meter. Jika letak puncak bayangan gedung sama dengan letak puncak bayangan Budi, berapakah jarak gedung dengan Budi? Selesaikan dengan berbagai macam cara.

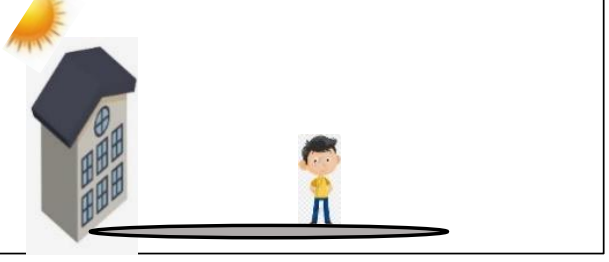

Gambar 2. Instrumen TKBK II

\section{HASIL DAN PEMBAHASAN \\ Hasil}

Hasil angket gaya belajar diikuti oleh 15 siswa ditunjukkan pada Tabel 2 berikut.

Tabel 2. Hasil Angket Gaya Belajar

\begin{tabular}{|c|c|}
\hline Kode & Gaya Belajar \\
\hline S1, S10, S14 & Kinestetik \\
\hline S2, S6, S7, S8, S11, S15 & Visual \\
\hline S3, S4, S5, S9, S12, S13 & Auditori \\
\hline
\end{tabular}

Setelah direkap, diperoleh 3 subjek memiliki gaya belajar kinestetik (20\%), 6 subjek memiliki gaya belajar visual (40\%), dan 6 subjek memiliki gaya belajar audiotori (40\%) 
dan subjek diberikan TKBK I. Hasil TKBK I seperti pada Tabel 3 berikut.

Tabel 3. Hasil TKBK I

\begin{tabular}{|c|c|}
\hline Kode & Tingkatan \\
\hline S1, S9, S11, S13 & 0.Tidak Kreatif \\
\hline S2, S3, S6, S10, S12, S14 & 2.Cukup Kreatif \\
\hline S4, S5, S7, S8, S15 & 3.Kreatif \\
\hline
\end{tabular}

Berdasarkan hasil TKBK I, 4 subjek $(26,67 \%)$ berada pada tingkatan tidak kreatif, 6 subjek $(40 \%)$ pada tingkatan cukup kreatif, dan 5 subjek $(33,3 \%)$ pada tingkatan kreatif. Hasil TKBK I tidak ada subjek yang menempati tingkatan sangat kreatif. Data ini dijadikan sebagai bahan pertimbangan untuk menentukan pemilihan subjek tahap berikutnya yaitu proses scaffolding sesuai gaya belajar bagi subjek yang masih berada pada tingkatan tidak kreatif.

Terdapat empat subjek dalam tingkatan tidak kreatif yaitu S1, S9, S11, dan S13. Masing-masing subjek bergaya belajar kinestetik (S1), auditori (S9 dan S13), dan visual (S11), dan subjek diberi nama S1K, S9A, S11V, dan S13A. Kemudian dilakukan wawancara pada keempat subjek untuk mengetahui alasan subjek tidak dapat menyelesaikan masalah pada TKBK I. Berdasarkan hasil wawancara, S1K, S9A, dan S11V tidak mampu merumuskan apa yang diketahui dan apa yang ditanyakan. Selain itu, materi kesebangunan dan kekongruenan yang diajarkan guru secara daring selama pandemi membuat mereka susah untuk memahami materi. Hasil wawancara dengan S13A, subjek mampu mengidentifikasi dan merumuskan apa yang diketahui dan apa yang ditanyakan namun kendalanya S13A lupa rumus sehingga tidak mampu menyelesaikan TKBK I. Saat wawancara S13A mampu merumuskan permasalahan sehingga S13A tidak dipilih sebagai subjek penelitian dan untuk gaya belajar auditori diwakili oleh S9A.

Pemahaman terhadap soal merupakan komponen penting dalam menyelesaikan masalah matematika, jika subjek tidak mampu merumuskan apa yang diketahui dan apa yang ditanyakan pada soal maka subjek tidak dapat menyelesaikan soal dengan benar. Jika seseorang tidak mampu memikirkan solusi bahkan tidak memahami masalah yang diberikan maka dia tidak akan mampu menciptakan solusi bagi masalah itu apalagi harus dituntun dengan berbagai cara yang baru bagi siswa, bahkan untuk mendapat pemikiran yang kreatif khususnya dalam matematika, diperlukan rasa ingin tahu yang tinggi dengan disertai proses eksplorasi dan pengamatan, imajinasi serta originalitas pemikiran yang tinggi (Vale \& Barbosa, 2015).

Berdasarkan uraian di atas, pemberian scaffolding diberikan kepada tiga subjek terpilih yaitu S1K, S9A, dan S11V. Ketiga subjek tersebut berada pada tingkatan tidak kreatif dan masing-masing mewakili gaya belajar. Scaffolfing diberikan secara bertahap sampai subjek memahami materi dan mampu menyelesaikan masalah yang diberikan. Scaffolding dibagi menjadi dua yaitu scaffolding pada TKBK I dan scaffolding pada TKBK II.

\section{Pemberian Scaffolding pada TKBK I}

Terdapat 3 level proses scaffolding yang diberikan, yaitu Pada level 1 (Enviromental provision), peneliti menyiapkan lingkungan belajar subjek dengan mengajak subjek berdoa sebelum pembelajaran dimulai, kemudian membangun komitmen belajar dengan meminta subjek untuk fokus belajar dan menanyakan hal-hal yang belum dipahami. Pada level 2 (Explaining, reviewing, and restructuring), peneliti menjelaskan kembali konsep kesebangunan dan kekongruenan, memberi contoh soal dan menerapkan konsep, serta memberikan contoh pemanfaatan dalam kehidupan sehari-hari. Pada level 3 (Developing conceptual thinking), peneliti meminta subjek untuk menjelaskan apa yang diketahui dan apa yang ditanyakan pada soal TBK1 dan memberi bantuan sampai subjek menemukan hasilnya. Berikut, proses pemberian scaffolding level 3 pada masing-masing subjek.

\section{a. Subjek S1K}

Peneliti meminta S1K menjelaskan apa yang diketahui dan apa yang ditanyakan pada TKBK1. S1K menjawab dengan benar tetapi tidak dapat menyelesaikan

masalah. Peneliti mengarahkan ke konsep kesebangunan tetapi S1K tidak memahami sehingga peneliti menjelaskan dengan menggunakan media kertas yaitu dua segitiga berukuran tidak sama tetapi sebangun. Ketika

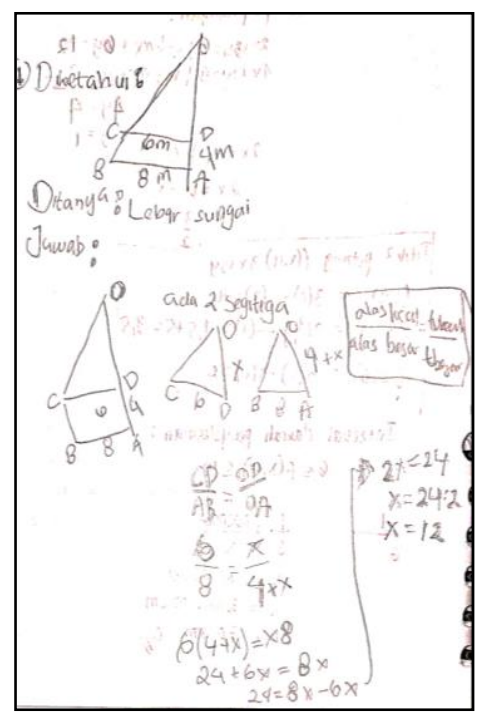

Gambar 3. Jawaban S1K pada TKBK I dua kertas segitiga diimpitkan, peneliti bertanya: "Apakah bentuknya sama seperti gambar pada soal?”. S1K mulai memahami dan peneliti meminta $\mathrm{S} 1 \mathrm{~K}$ untuk membuat dua segitiga yang sebangun seperti gambar pada soal. Namun S1K belum seutuhnya memahami apa yang diminta sehingga peneliti menjelaskan kembali menggunakan dua kertas segitiga yang diimpitkan. Segitiga yang besar diberi nama $\mathrm{ABC}$ dan segitiga yang kecil diberi nama DEC.

S1K juga membuat dua segitiga sebangun sesuai gambar pada soal dan memberi nama segitiga OCD dan 
segitiga OBA. Peneliti meminta untuk menentukan perbandingan sisi-sisinya tetapi $\mathrm{S} 1 \mathrm{~K}$ tidak bisa menjelaskan, sehingga peneliti menjelaskan bahwa perbandingan alas segitiga kecil dengan alas segitiga besar sama dengan perbandingan tinggi segitiga kecil dengan tinggi segitiga besar. Peneliti meminta S1K untuk menjelaskan perbandingan segitiga yang dimilikinya. Kemudian S1K menjelaskan bahwa lebar sungai tidak diketahui. Peneliti menjelaskan dan mengajukan pertanyaan: "Jika lebar sungai dimisalkan dengan x, berapa jarak pohon ke tongkat A?" Kemudian S1K memahami penjelasan peneliti dan menjawab dengan benar yaitu $\mathrm{x}+4$. Peneliti bertanya tentang sisi-sisi yang bersesuaian. Jawaban S1K: " $\frac{C D}{B A}=\frac{O D}{O A}$ kemudian $\frac{6}{8}=\frac{x}{x+4}$, sehingga hasilnya 12 ".

Pada level 3, pemberian scaffolding untuk S1K menggunakan alat peraga yaitu media kertas berbentuk segitiga. Alat peraga digunakan sebagai upaya membantu S1K memahami konsep dengan benar. Namun, S1K belum mampu menerapkan konsep kesebangunan pada penyelesaian dengan benar, sehingga peneliti memberi bantuan simulasi gambar dengan cara menggambar kembali dua segitiga yang sebangun. Setelah bantuan simulasi gambar ini, S1K mampu merumuskan penyelesaian masalah hingga menemukan solusi.

\section{b. Subjek S9A}

$\begin{array}{ll}\text { Peneliti meminta S9A } \\ \text { menjelaskan apa yang } \\ \text { diketahui dan } & \text { yang } \\ \text { ditanyakan } & \text { pada } \\ \text { TKBK1. } & \text { S9A } \\ \text { menjawab: } & \end{array}$

"Diketahui empat titik

$\mathrm{ABCD}, \quad \mathrm{AD}=4 \mathrm{~m}$, $\mathrm{AB}=8 \mathrm{~m}, \mathrm{CD}=6 \mathrm{~m}$ dan ditanyakan lebar sungai". Kemudian peneliti bertanya: "Bagaimana langkah yang akan kamu lakukan untuk mencari lebar

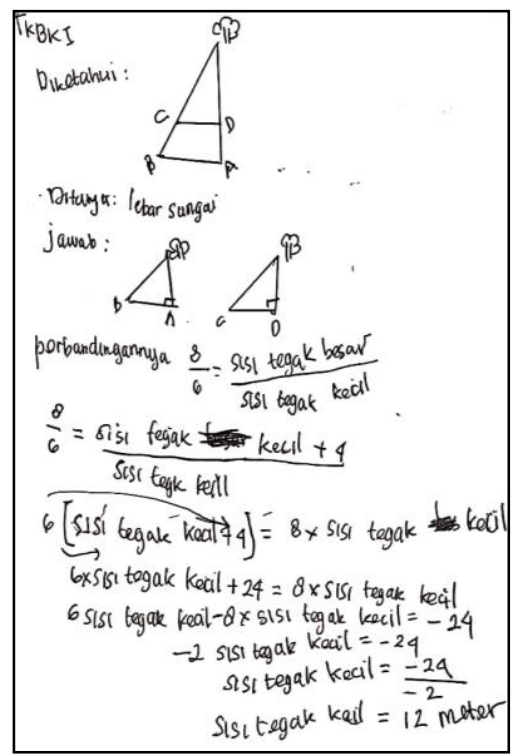
sungai?" Jawaban S9A yaitu "menggunakan

Gambar 4. Jawaban S9A pada TKBK I

kesebangunan, namun masih bingung cara menyelesaikannya". Peneliti mengarahkan ke konsep kesebangunan dengan menggunakan media kertas yaitu dua segitiga berukuran tidak sama tetapi sebangun. Ketika dua kertas segitiga diimpitkan, peneliti bertanya: "apakah bentuknya sama seperti gambar pada soal?". S9A mulai memahami dan peneliti meminta S9A untuk membuat dua segitiga yang sebangun dengan gambar pada soal, dan meminta S9A menulis perbandingannya.

Jawaban S9A : $\frac{8}{6}=\frac{\text { sisi tegak besar }}{\text { sisi tegak kecil }}$ tetapi sisi tegak besar dan kecil tidak diketahui. Peneliti menjelaskan bahwa sisi tegak besar bisa juga ditulis sebagai sisi tegak kecil ditambah 4. Jawaban S9A: $\frac{8}{6}=\frac{\text { sisi tegak kecil }+4}{\text { sisi tegak kecil }}$ tetapi S9A tidak bisa menyelesaikannya sehingga peneliti membimbing S9A dan meminta menyelesaikan persamaan: $\frac{2}{4}=\frac{x}{8}$; diperoleh $\mathrm{x}=4$, kemudian peneliti mengajukan pertanyaan: "bagaimana untuk $\frac{8}{6}=$ $\frac{\text { tinggi segitiga kecil }+4}{\text { tinggi segitiga kecil }}$ ?". Setelah mendapat penjelasan dan pertanyaan peneliti, S9A mampu menyelesaikan persamaan tersebut dengan menjawab tinggi segitiga kecil sama dengan 12.

S9A mampu mengkonstruksi konsep dengan benar, namun pada saat proses kalkulasi, S9A kurang memahami langkah menghitungnya sehingga peneliti memberi bantuan berupa contoh perhitungan yang serupa. Setelah pemberian bantuan, S9A dapat menyelesaikannya.

\section{c. Subjek S11V}

Peneliti meminta S11V untuk menjelaskan apa yang diketahui dan apa yang ditanyakan pada soal TKBK1. Jawaban S11V : "diketahui gambar seperti pada soal dengan ukuran $\mathrm{AD}=4 \mathrm{~m}, \mathrm{AB}=8 \mathrm{~m}, \mathrm{CD}=6 \mathrm{~m}$ yang ditanyakan lebar sungai". Peneliti mengajukan pertayaan: "Dapatkah kamu menerapkan konsep

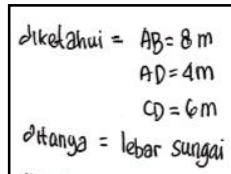
Jawab $=$

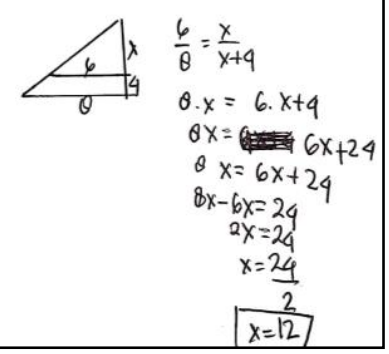
pada TKBK I
Gambar 5. Jawaban S11V

kesebangunan untuk menyelesaikan soal tersebut?". Jawaban S11V: "Saya bingung Bu, bentuknya tidak sama seperti rumus kesebangunan yang awal tadi, tinggi segitiga yang diketahui hanya yang bawah".

Peneliti meminta S11V untuk menggambar kembali segitiga tersebut menjadi dua segitiga yang sebangun dan memisalkan lebar sungai dengan $\mathrm{x}$, sehingga sisi tegak segitiga kecil diberi kode $\mathrm{x}$ dan sisi tegak segitiga besar ditulis $\mathrm{x}+4$. Kemudian peneliti meminta S11V untuk menemukan perbandingan sisi-sisi pada kedua segitiga sebangun tersebut. Dengan bimbingan peneliti, S11V dapat menuliskan: $\frac{6}{8}=\frac{x}{x+4}$ dan hasil akhirnya $\mathrm{x}=12$.

S11V menyelesaikan TKBK I, namun mengalami kesulitan dalam menentukan perbandingan sisi segitiga 
pada soal, sehingga peneliti memberi bantuan dengan menggambar kembali segitiga menjadi dua segitiga yang sebangun. Setelah menemukan perbandingan sisinya, S11V mengalami kesulitan kembali dalam menentukan panjang sisi yang tidak diketahui. Bantuan diberikan dengan menggunakan variabel untuk panjang sisi yang belum diketahui, akhirnya S11V dapat menyelesaikan TKBK I.

\section{Pemberian Scaffolding untuk TKBK II}

Pemberian Scaffolding pada TKBK II hanya diberikan pada level 3 (Developing conceptual thinking) karena level 1 dan level 2 dirasa sudah cukup diberikan pada proses scaffolding untuk TKBK I. Pemberian TKBK II bertujuan untuk mengetahui peningkatan pemahaman subjek dalam mengonstruksi konsep dengan benar serta mengetahui peningkatan kemampuan berpikir kreatif masing-masing subjek setelah diberikan scaffolding untuk TKBK I. Proses scaffolding dijabarkan sebagai berikut.

\section{a. Subjek S1K}

Pemberian Scaffolding pada S1K untuk TKBK II dimulai dengan pemberian soal TKBK II dan meminta $\mathrm{S} 1 \mathrm{~K}$ untuk membaca dan kemudian menjelaskan apa yang diketahui dan apa yang ditanyakan. S1K menggunakan konsep kesebangunan, menggambar serta memisalkan jarak gedung dan Budi dimisalkan $\quad \mathrm{x}$,

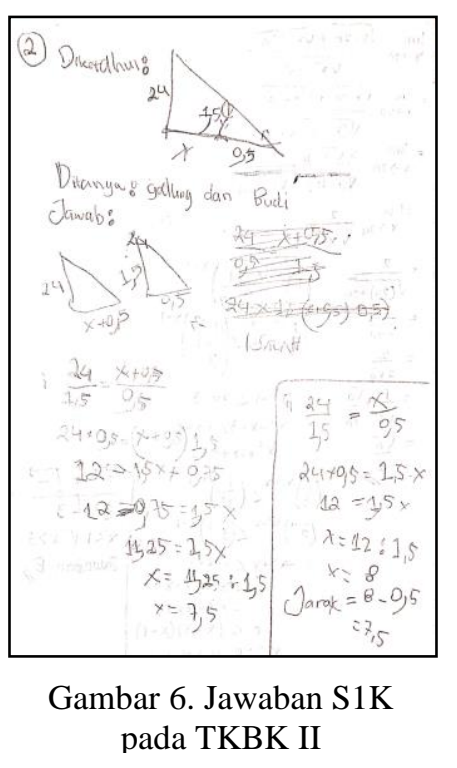
perbandingan sisisisinya $\frac{24}{1,5}=\frac{0,5}{x+0,5}$. Dalam proses penyelesaian, S1K salah dalam menentukan perbandingan sisi-sisi dua segitiga yang sebangun. Kemudian peneliti meminta untuk membetulkan kembali perbandingan sisi-sisinya. Sehingga S1K menulis kembali: $\frac{24}{1,5}=\frac{x+0,5}{0,5}$ dan hasilnya 7,5. Benar. Peneliti meminta S1K untuk menyelesaikan dengan cara yang lain. S1K menjawab :" $\frac{1,5}{24}=\frac{0,5}{x}$ lalu diperoleh $\mathrm{x}=8$, sehingga jarak gedung dengan Budi yaitu 8-0,5=7,5 meter."

Pada level 3 ini, S1K melakukan cara yang sama dengan pada level 3 untuk TKBK I yaitu menggambar kembali segitiga menjadi dua segitiga yang sebangun kemudian menentukan perbandingan sisi-sisinya. Namun S1K terbalik dalam menentukan perbandingan sisi, sehingga peneliti memberikan contoh perbandingan sisi untuk segitiga yang sebangun, S1K memahami kesalahannya dan menemukan penyelesaian. S1K mampu menemukan cara lain yang berbeda dari penyelesaian sebelumnya dengan membalik perbandingan sisi-sisinya. Dalam memecahkan masalah yang berkaitan dengan operasi aritmatika campuran, siswa belajar untuk merepresentasikan ide mereka dengan cara yang berbeda (Manoy, 2017).

b. Subjek S9A

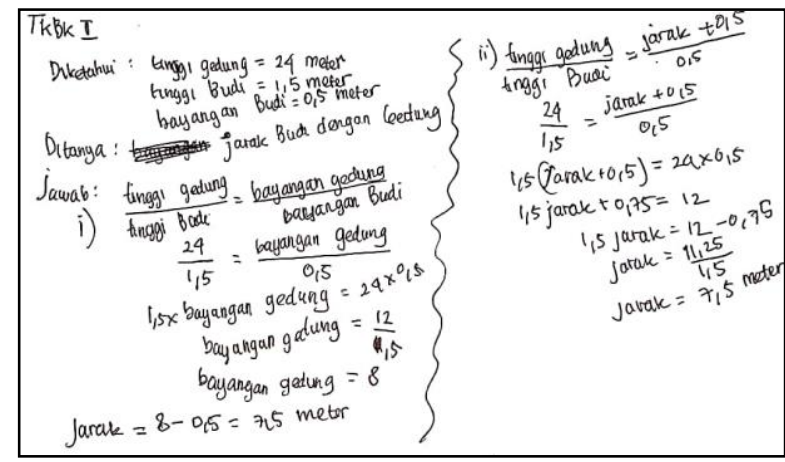

Gambar 7. Jawaban S9A pada TKBK II

Pemberian Scaffolding pada S9A untuk TKBK II dimulai dengan pemberian soal TKBK II dan meminta S9A untuk membaca dan kemudian jelaskan apa yang diketahui dan apa yang ditanyakan. S9A menjelaskan: "Diketahui tinggi Budi, panjang bayangan Budi, dan tinggi gedung, yang ditanyakan jarak gedung dengan Budi”. Kemudian peneliti bertanya: “Apa langkah yang harus dilakukan untuk menyelesaikan masalah tersebut?" Jawaban S9A : “ $\frac{\text { tinggi gedung }}{\text { tinggi Budi }}=\frac{\text { bayangan gedung }}{\text { bayangan Budi }}$ menjadi $\frac{24}{1,5}=$ $\frac{\text { bayangan gedung }}{0,5}$. Lalu dikali silang, panjang bayangan gedung=8. Jarak gedung dengan Budi dihitung dari panjang bayangan gedung dikurangi panjang bayangan Budi 0,5, hasilnya 7,5". S9A menjawab dengan benar. Pertanyaan peneliti: "Dapatkah kamu menemukan cara yang berbeda untuk menyelesaikan soal itu?". Peneliti memberi kesempatan S9A untuk berpikir, kemudian S9A menjawab: "Oh caranya hampir sama seperti soal pertama Bu. $\frac{24}{1,5}=\frac{\mathrm{Jarak}+0,5}{0,5}$ hasilnya 7,5 ”.

Pada level 3 untuk TKBK II, S9A dapat menemukan perbandingan sisi-sisi dua segitiga yang sebangun tanpa menggunakan bantuan. Pada proses penyelesaian, S9A belum berhasil menyelesaikannya, kemudian peneliti menanyakan kembali apa yang ditanyakan pada soal sehingga S9A menemukan hasil penyelesaian untuk TKBK II. S9A mampu menemukan cara lain yang berbeda dengan langsung mencari jarak dalam perbandingan sisisisi segitiga. Siswa dikatakan fleksibel jika siswa 
memecahkan masalah dengan satu cara kemudian menyelesaikan dengan cara lain (Manoy, 2014).

\section{c. Subjek S11V}

Pemberian Scaffolding pada S11V untuk TKBK II dimulai dengan pemberian soal TKBK II dan meminta S11V untuk membaca dan kemudian jelaskan apa yang diketahui dan apa yang ditanyakan.

Jawaban S11V: "Diketahui tinggi gedungnya 24, tinggi Budi 1,5 dan segitiga kecil DEF".Kemudian peneliti menanggapi dan bertanya: "Coba lihat kembali sisi yang bersesuaian saat

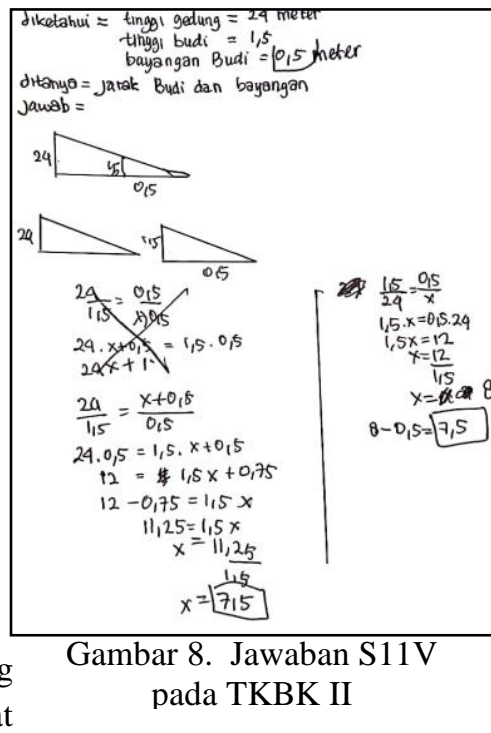
segitiga belum dipisah. Apakah akan ada titik yang sama ketika dipisah?". S11V menjawab: "Titik di depan Budi. Sehingga saya memberi nama segitiga besar $\mathrm{ABC}$ dan segitiga kecil DBE. $\frac{A C}{D E}=\frac{C B}{E B}$ maka $\frac{24}{1,5}=\frac{C B}{0,5}$. Hasilnya yaitu 8 meter". Peneliti mengarahkan subjek kembali: "Coba baca kembali soalnya. Apa yang ditanyakan?". S11V menjawab: "Jarak antara gedung dan Budi. Oh iya Bu, kurang. Berarti 8 dikurang 0,5 sama dengan 7,5 meter Bu." Kemudian peneliti bertanya: "Dapatkah kamu menyelesaikan masalah tersebut dengan cara lain yang berbeda?" S11V menjawab: "Jika saya misalkan $\mathrm{CB}=\mathrm{x}$.
Jadi perbandingannya $\frac{24}{1,5}=\frac{x+0,5}{0,5}$ Sehingga nilai $\mathrm{x}=7,5$. Wah jawabannya sama Bu."

Pada level ini, subjek S11V secara mandiri menerapkan bantuan yang diberikan peneliti pada level 3 untuk TKBK I. Subjek menggambar kembali segitiga yang diketahui menjadi dua segitiga yang sebangun. Namun terdapat kesalahan dalam pemberian nama titik, kemudian peneliti membimbing hingga S11V menemukan hasilnya.

\section{Pembahasan}

Pada level 1 awal proses scaffolding yang dilakukan yaitu menyiapkan lingkungan belajar subjek dengan cara mengajak subjek untuk berdoa sebelum pembelajaran dimulai. Kemudian membangun komitmen belajar dengan cara meminta subjek untuk fokus belajar dan menanyakan hal-hal yang belum dipahami. Hal ini bertujuan agar subjek termotivasi dan memiliki komitmen belajar sehingga proses scaffolding berjalan dengan baik.

Pada level 2, peneliti menanyakan permasalahan yang dihadapi saat mengerjakan TKBK I. Ketiga subjek tidak mengetahui apa yang diketahui dan apa yang ditanyakan serta tidak memahami konsep materi kecuali S11V. Sehingga peneliti memberikan konsep kesebangunan dan kekongruenan serta manfaat mempelajari konsep kesebangunan dan kekongruenan dalam kehidupan seharihari. Pemberian gambaran mengenai manfaat mempelajari materi kesebangunan dan kekongruenan juga merupakan pemberian motivasi pada subjek agar pemberian scaffolding berjalan dengan baik dan dapat membantu subjek dalam menyelesaikan masalah matematika yang diberikan. Level ini hanya diberikan pada proses scaffolding untuk TKBK I. Perbedaan proses scaffolding bagi masing-masing subjek pada level 3 untuk TKBK I dan TKBK II terdapat pada Tabel 4.

Tabel 4. Pemberian scaffolding level 3 pada TKBK I dan TKBK II

\begin{tabular}{cll}
\hline \multirow{2}{*}{ Subjek } & \multicolumn{1}{c}{ TKBK I } & \multicolumn{1}{c}{ TK } \\
\cline { 2 - 3 } & $\begin{array}{l}\text { Member } 3 \\
\text { segitiga sebangun kemudian menerapkan } \\
\text { dalam konsep perbandingan sisi }\end{array}$ & $\begin{array}{l}\text { Secara mandiri dapat menggambar } \\
\text { kembali dua segitiga yang sebangun }\end{array}$ \\
S1K & $\begin{array}{l}\text { Memberi bantuan dengan menggambar } \\
\text { kembali dua segitiga yang sebangun }\end{array}$ & $\begin{array}{l}\text { Terdapat kesalahan dalam menentukan } \\
\text { perbandingan sisi-sisi sebangun }\end{array}$ \\
& $\begin{array}{l}\text { Subjek tidak dapat menentukan } \\
\text { perbandingan sisi-sisi segitiga yang } \\
\text { sebangun }\end{array}$ & $\begin{array}{l}\text { Dapat menyelesaikan soal dengan dua } \\
\text { cara berbeda setelah diberikan bantuan } \\
\text { oleh peneliti }\end{array}$ \\
\hline \multirow{2}{*}{ S9A } & $\begin{array}{l}\text { Memberi bantuan dengan menggambar } \\
\text { kembali dua segitiga yang sebangun }\end{array}$ & $\begin{array}{l}\text { Tidak menggambar kembali dua segitiga } \\
\text { yang sebangun namun S9A menjelaskan } \\
\text { dengan benar dan dapat menemukan } \\
\text { perbandingan sisi-sisi sebangun }\end{array}$ \\
& $\begin{array}{l}\text { Subjek kurang memahami proses kalkulasi } \\
\text { aljabar sehingga peneliti memberi contoh } \\
\text { penyelesaian masalah aljabar sejenis }\end{array}$ & \\
\hline
\end{tabular}




\begin{tabular}{|c|c|c|}
\hline & $\begin{array}{l}\text { Subjek dapat menentukan perbandingan } \\
\text { sisi-sisi segitiga yang sebangun }\end{array}$ & $\begin{array}{l}\text { Dapat menyelesaikan soal dengan dua } \\
\text { cara berbeda tanpa diberikan bantuan } \\
\text { oleh peneliti }\end{array}$ \\
\hline \multirow[t]{2}{*}{ S11V } & $\begin{array}{l}\text { Memberi bantuan dengan menggambar } \\
\text { kembali dua segitiga yang sebangun } \\
\text { Subjek tidak dapat menentukan } \\
\text { perbandingan sisi-sisi segitiga yang } \\
\text { sebangun }\end{array}$ & $\begin{array}{l}\text { Dapat menggambar kembali dua segitiga } \\
\text { yang sebangun dan menemukan } \\
\text { perbandingan sisi-sisi sebangun namun } \\
\text { terdapat kesalahan pada penentuan titik } \\
\text { segitiga. }\end{array}$ \\
\hline & & $\begin{array}{l}\text { Dapat menyelesaikan soal menggunakan } \\
\text { dua cara berbeda tanpa diberikan bantuan } \\
\text { oleh peneliti }\end{array}$ \\
\hline
\end{tabular}

Pada proses scaffolding level 3 untuk TKBK I, peneliti dan subjek berdiskusi mengenai permasalahan yang dialami saat mengerjakan TKBK I. Subjek belum memahami apa yang diketahui dan apa yang ditanyakan sehingga subjek tidak bisa menyelesaikan soal dengan baik. Pemahaman terhadap soal merupakan komponen penting dalam menyelesaikan masalah matematika, karena ketidakmampuan siswa dalam merumuskan apa yang diketahui dan apa yang ditanyakan pada soal menyebabkan siswa tidak dapat melanjutkan penyelesaian masalah yang dihadapinya dengan benar (Hasan, 2015). Pada tahap ini, peneliti membimbing subjek untuk merumuskan kembali apa yang diketahui dan apa yang ditanyakan sehingga subjek dapat melanjutkan proses penyelesaian selanjutnya. Peneliti membimbing subjek untuk mengonstruksi konsep yang benar serta mengerjakan kembali TKBK I. Hal ini bertujuan agar subjek dapat memahami dan mengerti penerapan konsep kesebangunan dan kekongruenan dalam menyelesaikan TKBK I. Subjek diminta untuk mengerjakan TKBK I kembali karena pada saat penyelesaian awal, subjek tidak dapat menyelesaikan TKBK I. Proses yang telah dilakukan, menunjukkan bahwa pemberian scaffolding dapat membantu subjek dalam menyelesaikan masalah meskipun membutuhkan waku yang berbeda-beda.

Pada proses scaffolding level 3 untuk TKBK II, peneliti membantu subjek menyelesaikan TKBK II dengan cara mengkonstruksi konsep yang benar serta mendapatkan cara penyelesaian lain. Tujuan pemberian TKBK II yaitu untuk menguji pemahaman subjek terhadap konsep materi kesebangunan dan kekongruenan setelah diberikan TKBK I. Dalam penyelesaian TKBK II, masing-masing subjek tetap membutuhkan scaffolding dari peneliti walaupun membutuhkan waktu yang berbeda juga. Teknik dan lamanya pemberian scaffolding bergantung pada gaya belajar subjek dan kemampuan subjek mengikuti proses scaffolding (Wahyudi, 2017).

Total waktu yang dibutuhkan $\mathrm{S} 1 \mathrm{~K}$ dalam proses scaffolding TKBK I dan TKBK II yaitu 1 jam 22 menit. Sedangkan untuk S9A membutuhkan waktu 56 menit dan
S11V membutuhkan waktu 50 menit. Sehingga S9A dan S11V lebih cepat menerima dan memahami bantuan, sedangkan S1K membutuhkan waktu yang lebih lama dan penjelasan yang lebih rinci. S9A dan S11V menanggapi lebih cepat dibandingkan S1K. Jika subjek sudah mampu menyelesaikan masalahanya sendiri setelah scaffolding maka subjek akan menjadi pribadi yang mandiri dan percaya diri ketika diberi permasalahan mandiri (Akhtar, 2014).

Subjek menunjukkan kemampuan memahami soal setelah dilakukan pemberian scaffolding. Selain itu, subjek dapat menyelesaikan masalah pada TKBK II sesuai dengan pemahaman subjek. S1K mampu menemukan cara lain yang berbeda setelah peneliti membimbing dengan memberikan contoh soal lain dan penyelesaiannya. Sedangkan S9A dan S11V mampu menyelesaikan TKBK II dengan dua cara berbeda.

Pemberian scaffolding pada TKBK II menghasilkan kemampuan berpikir kreatif ketiga subjek meningkat. S9A dan S11V mampu menunjukkan indikator kefasihan dan fleksibilitas sehingga S9A dan S11V mengalami peningkatan dari tidak kreatif menjadi kreatif. S1K belum mampu menemukan cara lain secara mandiri maka subjek tidak memenuhi indikator fleksibilitas. Sehingga kemampuan berpikir kreatif S1K meningkat dari tidak kreatif menjadi cukup kreatif. Secara keseluruhan, ketiga subjek telah mampu memahami konsep dan menyelesaikan masalah yang diberikan. Hal ini menunjukkan bahwa scaffolding yang diberikan dapat membantu subjek dalam meningkatkan kemampuan berpikir kreatifnya.

\section{PENUTUP}

\section{Simpulan}

Alat peraga dan simulasi gambar membantu subjek gaya belajar kinestetik dalam memahami konsep materi kesebangunan dan kekongruenan. Sedangkan simulasi gambar membantu subjek gaya belajar audio dan visual dalam memahami konsep materi kesebangunan dan kekongruenan. Walaupun kecepatan subjek dalam menerima bantuan berbeda-beda, namun pemberian 
scaffolding lebih maksimal menggunakan alat peraga dan simulasi gambar.

Scaffolding sesuai gaya belajar dapat meningkatkan kemampuan berpikir kreatif matematis karena dapat memperbaiki pola berpikir subjek. Kemampuan berpikir kreatif matematis subjek dengan gaya belajar kinestetik meningkat dari tidak kreatif menjadi cukup kreatif, sedangkan subjek dengan gaya belajar audio dan visual meningkat dari tidak kreatif menjadi kreatif. Kecepatan subjek dalam menerima bantuan membutuhkan waktu yang berbeda-beda bergantung pada gaya belajar subjek dan kemampuan subjek dalam memahami materi. Subjek dengan gaya belajar visual dan audio lebih cepat menerima dan memahami bantuan, sedangkan subjek dengan gaya belajar kinestetik membutuhkan waktu yang lebih lama dan penjelasan yang lebih rinci. Sehingga scaffolding sesuai gaya belajar dapat meningkatkan kemampuan berpikir kreatif matematis siswa.

\section{Saran}

Serangkaian proses penelitian telah dilakukan peneliti sampai diperoleh simpulan, namun dalam prosesnya ditemukan beberapa kekurangan, sehingga saran peneliti sebagai berikut.

1. Indikator pengembangan soal TKBK I dan TKBK II perlu dirumuskan dengan baik sebelum melakukan penelitian.

2. Penentuan level untuk scaffolding bagi subjek berdasarkan analisa data hasil wawancara dan pekerjaan subjek. Sehingga scaffolding yang diberikan sesuai dengan kondisi subjek.

3. Media yang digunakan saat pemberian scaffolding kurang memenuhi syarat, sehingga untuk peneliti berikutnya harus mempersiapkan media yang lebih baik.

\section{DAFTAR PUSTAKA}

Akhtar, M. 2014. Patterns Of Scaffolding in One-to-One Mathematics Teaching: An Analysis. Educational Research International 3 (1): 71-79.

Anghileri, J. 2006. Scaffolding Practices that Enhance Mathematics Learning. Journal of Mathematics Teacher Education 9 (1): 33-52.

Azhari, dan Somakim. 2014. Peningkatan Kemampuan Berpikir Kreatif Matematik Siswa melalui Pendekatan Konstruktivisme di Kelas VII Sekolah Menengah Pertama (SMP) Negeri 2 Banyuasin IN. Jurnal Pendidikan Matematika 8 (1).

Badjeber, Rafiq, dan Jayanti Putri Purwaningrum. 2018. Pengembangan Higher Order Thinking Skills dalam Pembelajaran Matematika di SMP. Jurnal Pendidikan dan Pembelajaran 1 (1): 36-43.

Brookhart, Susan M. 2010. How to assess higher-order thinking skills in your classroom. ASCD Alexandria, Virginia USA
Choridah, D, T. 2013. Peran Pembelajaran Berbasis Masalah untuk Meningkatkan Kemampuan Komunikasi dan Berpikir Kreatif serta Disposisi Matematis Siswa SMA. Infinity Journal 1-9.

DePorter, B., dan M. Hernacki. 2008. Quantum Learning: Membiasakan Belajar Nyaman dan Menyenangkan. Translated by Alwiyah. Bandung: Kaifa.

Fardah, Dini Kinanti. 2012. Analisis Proses dan Kemampuan Berpikir Kreatif Siswa dalam Matematika melalui Tugas Open-Ended. Jurnal Matematika Kreatif-Inovatif 3 (2).

Fayombo, G. 2015. Learning Styles, Teaching Strategies and Academic Achievement Among Some Psychology Undergraduates in Barbados. Caribb Education Res. J. University West Indies 5 (2): 46-61.

Hamzah, 2008. Orientasi Baru Dalam Psikologi Pembelajaran. Jakarta: PT Bumi Aksara.

Hasan, Buaddin. 2015. Penggunaan Scaffolding untuk Mengatasi Kesulitan Menyelesaikan Masalah Matematika. APOTEMA 1 (1): 88-97.

Heong, Y. M, dkk. 2011. The Level of Marzano Higher Order Skills among Technical Education Students. International Journal of Social Science and Humanity 1 (2): 121-125.

King, FJ., Goodson Ludwika., Rohani Faranak. 2018. Higher Order Thinking Skills" A publication of the Educational Services Program. www.cala.fsu.edu

Manoy, Janet Trineke. 2014. Creative Problem Solving with Higher Order Thinking Problem in Learning Mathematics. International Seminar on Innovation in Mathematics and Mathematics Education ( Yogyakarta State University) 289-294.

Manoy, Janet Trineke. 2017. Elementary students' representations in solving word problems. Journal of Physics: Conference Series (IOP Publishing).

Munandar, U. 2014. Pengembangan Kreativitas Anak Berbakat. Jakarta: Rineka Cipta.

Nursalam, Andi Dian Angriani, Darmawati, Baharuddin, and Aminuddin. 2018. Developing Test Instruments for Measurement of Students' High-Order Thinking Skill on Mathematics in Junior High School in Makassar. Journal of Physics: Conference Series 1028 (IOP Publishing).

OECD. 2019. Indonesia-Country Note-PISA 2018 Results. OECD Publishing 1. https://www.oecd.org/pisa/publications/PISA2018_C N_IDN.pdf.

OECD. 2018. PISA 2018: Insight and Interpretations. OECD Publishing 7.

Permatasari, Galuh Indah, Azin Taufik, dan Nuranita Adiastuty. 2018. Analisis Kemampuan Berpikir Kreatif Matematis melalui Pembelajaran Model 4K Ditinjau 
dari Gaya Belajar SIswa. Seminar Nasional Pendidikan Matematika 29-39.

Siswono, Tatag Yuli Eko. 2010. Leveling Student's Creativity in Solving and Posing Matehematical Problem. IndoMS.J.M.E 1 (1): 17-40.

Siswono, Tatag Yuli Eko. 2007. Konstruksi Teoritik Tentang Tingkat Berpikir Kreatif Siswa dalam Matematika. Jurnal Universitas Adibuana.

Sriwongchai, Arunee, Nirat Jantharajit, dan Sumalee Chookhampaeng. 2015. Developing the Mathematics Learning Management Moderl for Improving Creative Thinking in Thailand. International Education Studies 8 (11).

Vale, I, dan A. Barbosa. 2015. Mathematics Creativity in Elementary Teacher Training. Journal of the European Teacher Education Network 10: 101-109.
Wahyuni Yusri. 2017. Identifikasi Gaya Belajar (Visual, Auditorial, Kinestetik) Mahasiswa Pendidikan Matematika Universitas Bung Hatta. JPPM Vol. 10 No. 2

Wahyudi. 2017. Scaffolding Sesuai Gaya Belajar Sebagai Usaha Meningkatkan Kemampuan Berpikir Kreatif Matematis. Jurnal Pendidikan Dasar dan Pembelajaran (Premiere Educandum) 7 (2): 144-157.

Widodo, Tri, dan Sri Kadarwati. 2013. Higher Order Thinking Berbasis Pemecahan Masalah untuk Meningkatkan Hasil Belajar Berorientasi Pembentukan Karakter Siswa. Cakrawala Pendidikan 32 (1): 161-171.

Zahroh, U. \& A. Beni. 2014. Kecenderungan Gaya Belajar Mahasiswa dalam Menyelesaikan Masalah Fungsi Bijektif. Jurnal Kebijakan dan Pengembangan Pendidikan 2(1). 